\title{
ENTRE O ESTADO E A SOCIEDADE - CIRCULAÇÃo DE PROFISSÕES DA ELITE DA POLÍTICA
}

\author{
Esser Silva \& Moisés de Lemos Martins
}

\begin{abstract}
RESUMO
Este artigo pretende, por um lado, explorar as ordenações teóricas que traçam a formação da classe eleita - ou as elites - transcorrendo a sua afirmação da circulação das profissões que acedem ao campo político e, por outro, entrecruzando os estudos de Foucault sobre parresía e elutéria com a noção weberiana de fechamento partidário, compreender o modo como os profissionais da política articulam a sua existência entre a vida civil e a vida estatal. Assim, esta análise orienta-se para a compreensão dos traços distintos dos grupos profissionais, enquanto característica objetiva para acesso e uso do poder em benefício próprio. Assente num estudo, que tem por base o caso dos deputados da Assembleia da República Portuguesa e na constatação que nela predominam "economistas", "advogados" e "professores", enquanto membros ativos, escrutam-se duas ordenações em coabitação nesta classe eleita: por um lado, entre o desapego, a ausência de medo e a capacidade de agir francamente, enunciados como qualidades interiores constituintes do político, e por outro lado, as práticas exteriorizadas com fins acobertados nas estratégias dos aparelhos partidários, formam-se duas configurações de sentido - a do político inteiro e a do político fracionado, ambos cultivados numa coexistência hegemónica, que enuncia, como modo extensivo da política, a transmutação da solidariedade ideológica para a introdução do antagonismo económico.
\end{abstract}

\section{Palavras-chave}

Parresía; elite; fechamento; profissionais extrapolítica; legitimação

\begin{abstract}
This article aims to explore the theoretical structures that influence the formation of the elite class - or the elites - analysing the affirmation of these structures within the circulation of professions that have access to the political sphere, while comparing Foucault's studies on parrhesia and eluteria with Weber's concept of social closure by means of political parties, to understand how political professionals articulate their existence between civil society and public service. This analysis is orientated towards understanding the distinct traits of professional groups, as an objective characteristic for access to, and use of, power for personal benefit. Based on a study of MPs of the Portuguese Assembly of the Republic and the finding that "economists", "lawyers" and "teachers" are the predominant professions, detailed analysis is provided of two structures of cohabitation within this elite class: characterised on the one hand, by nonchalance, fearlessness and the capacity to act frankly, enunciated as constituent inner qualities of any politician, and on the other hand, by externalized practices, with hidden goals in the strategies of the party apparatuses. These two structures establish two configurations - that of the full-time politician and that of the fractioned politician, both of which are cultivated in a hegemonic coexistence, which expresses, as an extensive mode of politics, a transmutation of ideological solidarity for the introduction of economic antagonism.
\end{abstract}

\section{PALAVRas-Chave}

Parrhesia; elite; closure; extra-political professionals; legitimisation 


\section{INTRODUÇÃo}

A elite política pode ser identificada, a partir das profissões com predisposição para o acesso aos lugares de representação política (Gaxie, 1980). As profissões dos deputados à Assembleia da República portuguesa, cuja origem é civil, constituem o indicador conveniente para prover, não só a estatística desses profissionais, como permitir a compreensão das dinâmicas e transformações ocorridas no político (Parsons, 1939). Tendo Gaxie (1980) como precursor, o estudo do fenómeno das profissões na política tem merecido a atenção em Portugal de alguns estudos, como são os casos de Braga da Cruz (1988), Freire (1998), Belchior (2011), Lisi (2011) e Jalali (2017). Os estudos assinalam, genericamente, as variações com origem na dinâmica societal em geral, que se introduzem na política (Jalali, Silva \& Silva, 2012; Joly, 2005), concorrendo para um meIhor conhecimento das atividades que têm maior predisposição para ocupar o espaço de mediação e influência nas relações de reciprocidade, trocadas entre a Sociedade Civil (Fernandes, 2014) e o Estado (Bourdieu, 2012; Burton \& Higley, 2001).

É comummente aceite que os atributos das elites, nomeadamente no que respeita ao grau da sua coesão, consciência de si, estratégias e práticas, só podem ser conhecidos através de "investigação empírica", devendo nesta fazer-se a distinção, "de modo consistente, entre "elites" e "não-elites" (Higley, 2010, p. 17). A natureza simplificada desta premissa deve ser acolhida de acordo com um olhar crítico, na medida em que, sem este cuidado, o exame e a interpretação das práticas correm o risco de verem distorcida a "verdadeira estratificação política das sociedades" em análise (Higley, 2010, p. 17). A separação entre "elites" e "não-elites" exprime a oportunidade para utilizarmos, enquanto recurso técnico, a criação de um quadro de experiência analítico (Goffman, 1986), formado de acordo com uma simplificação da realidade. O tipo ideal, constructo weberiano formado a partir de algumas características do sujeito enquanto objeto, permite alcançar o conhecimento acentuando a transversalidade e o aprofundamento dos aspetos particulares de um dado fenómeno, estudando-o de forma isolada (Weber, 2005b).

Quais são, como se distribuem, que dinâmicas, coletivas e individuais, apresentam as profissões que denotam tendência para ocupar o espaço da elite da política portuguesa entre 1974 e 2015? O conhecimento assim obtido permite identificar as profissões com estratégias mais ativas no relacionamento com o campo em análise. E da mesma forma, permite promover a compreensão do fenómeno político, segundo um ponto de vista diferenciador (para além da clássica divisão em partidos políticos), capaz de explicar as vias de ligação valorizadas na Sociedade Civil, para aceder e dispor do funcionamento do aparelho de Estado, de acordo com modalidades adequadas ao benefício a retirar.

\section{VONTADE PRÓPRIA E PASSO EM FRENTE}

O principal empreendimento do indivíduo, identificado como agente político, é o de compreender as leis subjacentes ao governo de si, que possam servir ao governo de todos os outros, seus compatrícios (Foucault, 1994, 2008; Martins \& Neves, 2000). À 
partida, o direito à politeia, ou à cidade, estende-se a todos aqueles que são constituídos como cidadãos; no caso, exclusivamente os que têm direito de voto. A isonomia, "igualdade de todos perante a lei" (Foucault, 2008, p. 138), garante-o. Mas não chega pertencer à politeia para se ganhar o direito a ser um eleito, característica exclusiva dos escolhidos para "representar". Para se ser um escolhido - um representante, é necessário que se possua determinadas virtudes, que destacam e colocam o cidadão na "primeira fila".

A primeira dessas qualidades é estar guarnecido pela eleutéria, estado de liberdade interior exigido a todo o político, um pressuposto que se traduz na capacidade de ser independente e que assenta no princípio de que não há poder "detido de maneira despótica ou tirânica por um só chefe" (Foucault, 2008, p. 138). Trata-se, antes de tudo, de não ter medo do poder, residindo este, tanto nas mãos de outros, como em rédeas próprias. A posse de eleutéria fica desde logo manifestada no cidadão que avança para a "primeira-fila", um ato que não tem precedência e que decorre exclusivamente da vontade própria (Rothe, 2011).

A outra qualidade é o direito ao verbo, como modo de existir na cidade. A isegoria alude ao princípio da igualdade da palavra, como um direito universal de todo aquele que é constituído cidadão. Mas a isegoria, ao estabelecer o direito de falar, não garante, só por si, o aparecimento de indivíduos dotados de idiossincrasia singular e verve peculiar. Para além do direito à palavra, em si constituído, é exigido ao indivíduo aspirante a posse de livre arbítrio como alicerce, qualidade que o habilita e norteia para um ato distinto e intrépido, identificado na "liberdade de tomar a palavra e de exercer a fala franca, na palavra" (Foucault, 2008, p. 139). Obriga-se, para tal, a socorrer-se de "manifestações de verdade, uma série de operações e de procedimentos pelos quais a verdade é dita" (Foucault, 2008, p. 139), dando corpo a uma conduta designada por parresía, noção que, à partida, evoca o exercício do verbo com sinceridade e sem segundas intenções.

A parresía funda-se no princípio da verdade oracular, que dá ao prognóstico os contornos antecipados de autenticidade e precisão (Rothe, 2011). É o ponto de ancoragem de todo o indivíduo postulado para o campo político e, do mesmo modo, constitui também a dimensão iniciática e o próprio fundamento da democracia. Trata-se do resultado antevisto da "busca" (Foucault, 2008, p. 141) de todos os que procuram deter-se na coisa pública e sentem possuir qualidades virtuosas.

Mas como toda a práxis política, a parresía configura "um direito humano, um risco humano" (Foucault, 2008, p. 141). É uma elucubração cometida ao sentido da existência humana, e que, simultaneamente, constitui o político e é pilar da democracia, inexistindo um sem o outro (Foucault, 2008, p. 142). Esta circularidade não encerra, todavia, as possibilidades de destrinça das "relações entre parresía e democracia" (Foucault, 2008, p. 142), especialmente nos modos como é reconhecida a parresía no indivíduo. Apenas o seu detentor se aproxima da frente, em direção ao "pequeno grupo de pessoas que constituem a primeira fileira de cidadãos" (Foucault, 2008, p. 142) e que, tal como no caso do soldado corajoso e virtuoso, avança, destacado, para a primeira linha de combate. 


\section{ENTRE A PARRESÍA E A DOMINAÇÃo DA CLASSE ELEITA}

A obrigação autoimposta do discurso de verdade não encerra em si toda a noção de parresía. $\mathrm{Na}$ antecâmara da sua formulação conceptual está a politeia e o direito igual dos cidadãos usarem da palavra. A parresía é mais do que esse direito constituído de tomar a palavra e falar. É, também, o elemento que permite que os indivíduos "adquiram certa ascendência uns sobre os outros" (Foucault, 2008, p. 145), autorreconhecendo em si componentes de diferenciação, no caso, autorreconhecendo uma espécie de convocatória para avançar para a linha da frente, onde, ultrapassada a fronteira, se dirigem aos "outros para lhes dizer o que pensam, o que pensam ser verdade, o que pensam verdadeiramente ser verdade" (Foucault, 2008, p. 145) e, exclusivamente com a verdade, jamais iludindo ou defraudando, persuadir com bons conselhos "e assim dirigir e ocupar-se da cidade" (Foucault, 2008, p. 145), governando os outros com o melhor de si'.

A superioridade aqui constituída não decorre de uma predominância exclusiva, mas sim, de uma superioridade partilhada "com outros sob a forma da concorrência, da rivalidade, do conflito, da liça" (Foucault, 2008, p. 145) e que introduz o princípio de emulação, tendo em vista provocar um tipo de competição tendente a exceder as melhores qualidades. Nesse sentido, a parresía constitui-se numa "estrutura agonística" (Foucault, 2008, p. 145), na qual emerge algo mais do que um estatuto, na medida em que se introduzem outros cambiantes, fundados nos princípios de uma "estrutura dinâmica" (Foucault, 2008, p. 145). É esta dinâmica que congrega em si o movimento capaz de colocar o político no lugar de se ocupar "da cidade na forma e pelo exercício do discurso verdadeiro" (Foucault, 2008, p. 145). É também nessa função que o político, usando as suas próprias qualidades e, principalmente, experimentando a posse do poder, se descobre apartado e separado do comum dos cidadãos, com a possibilidade do exercício de atos de dominação (Weber, 2004).

Esta condição dominadora, circunscrita à afirmação e renovação do poder, é uma realidade transversal a todo o mundo civilizado (Mills, 1956). Contrariamente à posse de parresía, a transmissão dessa estabilização faz-se na corrente hereditária e "num contínuo trabalho de endosmose e exosmose entre a classe alta e algumas rações das baixas" (Mosca, 1923, p. 69). O processo da classe política estável só termina, quando as qualidades em si reconhecidas perdem valor e importância e deixam de servir socialmente.

É num quadro maleável que Pareto (2004), seguindo a linha de raciocínio de Mosca (1923), concebe uma formulação, em que os indivíduos mantêm a possibilidades de ascender na escala social. À visão imaginada "da sociedade" homogénea, encarada a partir do exterior, Pareto contrapõe a sociedade heterogénea, formada nos interstícios das suas adições e contradições. Parte do princípio de que, no interior das nações civilizadas, se vive uma plasticidade dinâmica, resultante da ação e mobilidade dos seus componentes, dando-se, desta forma, "uma intensa circulação entre as várias classes" (Pareto, 2004, p.

\footnotetext{
' Tem cabimento, neste contexto, abrir espaço para o debate sobre a palavra usada publicamente. Ver, a este propósito, Roland Barthes, sobre L'ancienne rhétorique (1970), e também o número 16, da revista Comunicação e Sociedade, "Comunicação, argumentação e retórica" (Martins \& Grácio, 2009), assim como o artigo "A epistemologia do saber quotidiano" (Martins, 1993).
} 
449). São as qualidades dos indivíduos que tornam possível a existência de vários graus na composição da escala social. A divisão estratificada permite separar aqueles que apresentam qualidades excecionais e que acabam localizados nos lugares "mais elevados no ramo da sua atividade" (Pareto, 2004, p. 451). Pareto nomeia essa categoria de classe eleita, querendo afirmar também que se trata da "elite". Divide-a em duas frações: a "classe eleita de governo" e a "classe eleita de não governo" (Pareto, 2004, p. 451). No cômputo geral, a totalidade da classe eleita forma a classe superior. Abaixo desta localizam-se os estratos inferiores que, globalmente, dão expressão à classe não eleita.

A "classe eleita do governo" distingue-se da "classe eleita do não governo" por albergar os notáveis, nos quais as etiquetas hereditárias desapareceram. Mas, indiretamente, o poder hereditário "permanece poderoso" mantendo-se o princípio de que "quem herdou um grande património (...) faz-se eleger deputado, pagando aos eleitores, adulando-os", criando um cenário no qual "a riqueza, o parentesco, as relações" (Pareto, 2004, p. 452) funcionam como alavancas para elevar até à classe eleita, em geral, e à classe eleita de governo, em particular, indivíduos que nuns casos têm, e noutros não, as qualidades de partida para tal.

Para Higley (2010), tanto Mosca como Pareto apresentam perspetivas demasiado assentes nas teorias críticas reprodutivas, com as elites a constituírem-se como um grupo recortado, segundo contornos de distinção e pertença, suportados por "superiores qualidades individuais, sejam de inteligência, de talento e de magnetismo pessoal" (Higley, 2010, p. 15). Esta ideia entronca na difusão muito ampliada de que o destino está traçado, à partida, segundo um sistema estabelecido de reprodução social, constituído de acordo com uma base que justifica a captação e circulação de "dotes e vantagens sociais individuais" (Higley, 2010, p. 15), entre indivíduos que se reconhecem e se fazem reconhecer entre si. Este entrançado da elite baseia-se num tipo de coesão particular, com os membros aparentemente desligados e uma vinculação silenciosa, mas vigorosamente alicerçada na posse do poder.

\section{UNIFICAÇÃO E FECHAMENTO DA ELITE}

A perceção que temos de uma elite está tão diluída em nós, que Higley admite estar à partida condenado qualquer processo tendente a erradicar dotes e vantagens sociais, que possam limitar o seu papel. Com efeito, uma elite estabelece-se de modo invisível, sem qualquer expressão organizada de coletividade e sem interesses transversais, suscetíveis de serem transformados num manifesto ou numa organização política. Ao contrário das coletividades, as elites são "ambíguas e vagas" (Higley, 2010, p. 15). Não são atravessadas por "entendimentos sociais e culturais", a ponto de nem sequer as gratificações ansiadas pelos seus membros decorrerem da reivindicação de "estatutos e objetos de valor", seja para o próprio, seja para os aliados (Higley, 2010, p. 15), pelo que "só em parte são compatíveis com as satisfações procuradas por outros" (Higley, 2010, p. 15).

Independentemente do país em análise e da existência ou não de estabilidade no seu sistema político, a tendência para o controlo e a "manipulação personalizada", através de 
vários tipos de forças, ocorre frequentemente por indivíduos ou grupos constituintes das elites, os quais, independentemente das suas simpatias partidárias, interpretam o poder como algo de pessoal e "diretamente dependente do apoio de forças coercivas orgânicas" (Higley, 2010, pp. 18-19). Para os indivíduos da alta sociedade, o poder não decorre da ocupação de "posições institucionais", definidas na organização política, mas sim do "sucesso de determinado grupo específico, em obter as rédeas dos principais meios de coerção" (Higley, 2010, p. 19). Este propósito, presente em todos os grupos de elites, não apenas exprime uma congénita desconfiança relativamente ao próprio grupo, como, por outro lado, assinala uma infindável predisposição para a luta, em que são "plausíveis e até prováveis" as tentativas de tomada do poder (Higley, 2010, p. 19). Estas configurações chegam a assumir contornos de "elite desunida", caracterizada pela instabilidade do sistema político, o qual muitas vezes se vê submetido a alterações "profundas e bruscas", sem que as consequências das lutas sejam antecipadamente consideradas.

A elite desunida tem expressão prática no recorte das diferenças e das lutas permanentes, tomadas como atos naturais produzidas nas contendas da democracia. As relações no campo político, entendidas como voláteis e descartáveis, vivem em constante alteração "segundo as forças e os poderes que se ligam uns com os outros ou que se separam entre si para se afirmarem" (Schmitt, 2015, p. 30). Esta visão segue a perspetiva amplamente debatida, e não menos vezes refutada, segundo a qual a essência da política (Freund, 1969) assenta no princípio radical em que as partes vivem em permanente estado antagónico, o que separa as partes entre amigo e inimigo (Schmitt, 2015).

Por sua vez, a elite unificada emerge na decorrência da ausência de instabilidade e tomadas abruptas de poder. O respeito por aquilo que a sociedade designa como expressão da autoridade, inscrevendo "procedimentos institucionalizados perpetuados e estabilizados durante longos períodos" (Higley, 2010, p. 20), parece ter como explicação o comportamento dos indivíduos que formam a cúpula societal. Não se infira daqui a ideia da implantação de uma espécie de acordo tácito de não-agressão entre os grupos de elites. A dimensão primordial da estabilidade localiza-se no campo político e tem relação com o "agir com autoridade", na justa medida em que não se deve convocar a hostilidade dos que estão ativos na disputa pelos bens de valor, nem levar os inativos a abraçar esse "sentimento hostil" (Higley, 2010, p. 20). A estabilidade política é obtida em processo dinâmico de interação entre dissemelhantes, constituindo-se num "produto artificial de decisões astutas tomadas pelos indivíduos realmente influentes" (Higley, 2010, p. 20), os quais, por sua vez, não se coíbem de utilizar subterfúgios e ardis, consubstanciados "na supressão, distorção ou manipulação de questões", de forma direta ou indiretamente participada na tomada de decisões, e cujo desconhecimento do público em geral, assim como a manutenção do "segredo" que lhe subjaz, sob reserva de alguns, evita um "conflito desastroso" (Higley, 2010, p. 20).

A capacidade de manutenção em segredo do uso da astúcia, como prática no interior de um círculo de grupos diferenciados da alta sociedade, implica uma confiança mínima no seu meio, "no sentido de não expor os seus estratagemas" (Higley, 2010, pp. 2021), de modo a ocultar as ações percetíveis do quotidiano. Esta concertação, próxima de 
uma "conspiração dos influentes e decisores efetivos", consolida não só um acordo "em torno da desejabilidade de um sistema político estável", como também revigora o compromisso entre grupos que arquitetam "uma elite unificada" (Higley, 2010, pp. 20-21).

Podemos caraterizar as elites em dois tipos distintos: as elites "ideologicamente unificadas" e as "elites consensualmente unificadas" (Higley, 2010, p. 21). O primeiro tipo caracteriza-se pela adesão a uma ideologia única, expressa, em geral, no seguimento da emergência de um líder tido como homogéneo, e também pelo facto de ser possível evitar conflitos, em público, entre os seus aspirantes. A concórdia que se exprime nas ações públicas configura, desta forma, um dispositivo de poder "capaz de forçar a totalidade ou a maior parte dos indivíduos da elite (...) a harmonizar as suas declarações públicas com a ortodoxia" (Higley, 2010, p. 21). Esta, por sua vez, dado ser imposta pelos indivíduos autorizados a definir os preceitos, os indivíduos de topo, usa a severidade e o controlo como formas de bloqueio da "expressão dos interesses divergentes" (Higley, 2010, p. 21).

No que respeita à "elite consensualmente unificada" podemos dizer que ela se constrói segundo a adesão a formas diferenciadas do campo político. E os seus membros, detentores ou perseguidores do poder, não se coíbem de assumir "posições claramente divergentes sobre as questões públicas" (Higley, 2010, p. 21). A situação conflitual implicada neste tipo de elite configura um antagonismo de forças. Este antagonismo revê-se, todavia, num "conjunto de regras", naturalizadas como primordiais, porém não prescritas, mas tidas como indispensáveis "para eliminar os riscos pessoais graves das disputas entre elites" (Higley, 2010, p. 22). A disputa impõe, neste caso, um limite demarcado nos interesses gerais, que a atuação dos atores políticos não olvida e que configura um encerramento, ou fechamento.

A noção de fechamento compreende os contornos sociais de reivindicação de prestígio e de honraria social, que um grupo se (auto)atribui, através do apelo tácito, em permanência reativado, de um recorte honorífico (Weber, 2004). Supõe um apelo constante de separação, fazendo-se distinguir pelos traços de dignidade e posse de propriedades peculiares e exclusivas dos seus membros. Como nas sociedades medievais, o círculo gerado pelo fechamento assemelha-se a um domínio, não de possessões corpóreas, mas de configurações imateriais, as quais, regra geral, formam um monopólio.

Existe monopólio sempre que um "agrupamento impõe um fechamento, em limites variáveis, tendo em vista aumentar as oportunidades de sua atividade contra os que ficam do lado de fora" (Freund, 2003, p. 115). O monopólio constitui a superior representação prática de um sistema fechado, que promove um privilégio, e a sua forma típica, na história, é localizada na "corporação" (Freund, 2003, p. 116). Por sua vez, é da natureza de uma corporação submeter os seus futuros membros a um tirocínio, que tem como objetivo a aprendizagem do funcionamento do seu sistema organizacional, visando a manutenção do seu monopólio ao longo dos tempos (Dal Bó, Dal Bó \& Snyder, 2009).

A partir deste entendimento forma-se um juízo darwinista, que conduz à autoatribuição de qualidades sanguíneas especiais, constitutivas de uma putativa classe superior de políticos. Esta falácia, repetida muitas vezes e anunciada como uma verdade, 
inspira Mosca (1923) a considerar uma outra via de conservação da elite da política. Essa outra via é fundada no culto da dimensão educacional. Um tal culto determina, como fatores para justificar as qualidades destacadas dos indivíduos da aristocracia, a esmerada e "particularíssima educação". Apesar da posse de competências escolares explicarem a superioridade no conhecimento e a graça virtuosa das "atitudes puramente intelectuais" (Mosca, 1923, p. 67), esta dimensão não esclarece "as diferenças de carácter moral, como seriam a força de vontade, a coragem, o orgulho, a energia" (Mosca, 1923, p. 67), apresentadas pelos indivíduos como uma propensão para "o passo em frente", a que alude Foucault. Não restam dúvidas, portanto, de que as condições sociais resultantes do nascimento, especificamente a "posição social, as tradições de família, os hábitos de classe" (Mosca, 1923, p. 67), acabam por se constituir numa presença fortalecida e determinante na preparação integral do indivíduo, contribuindo, praticamente sem qualquer esforço, mas como se decorresse da intervenção de um destino predestinado, "para o maior ou menor desenvolvimento" (Mosca, 1923, p. 67) das qualidades pessoais apresentadas.

\section{Profissões Civis da elite política}

De acordo com Gaxie (1980), a última profissão do indivíduo antes da sua entrada na política, além do lugar e da posição sociais ocupadas por essa mesma profissão, é que determinam a probabilidade de acesso a altos cargos e exercício do poder na hierarquia política. É essa a razão que permite a conclusão de que existe uma "correlação estreita entre a representação política de um grupo e a posição social de seus membros" (Gaxie, 1980, p. 5). Essa relação anuncia uma sobrerrepresentação das categorias profissionais, oriundas das classes superiores, e uma sub-representação - ou mesmo ausência de representação - das "frações das classes médias ou populares - com a significativa exceção dos professores primários", verificando-se, desta forma, uma imagem “invertida da estrutura social" (Gaxie, 1980, p. 6).

Esta situação paradoxal da representação revela o monopólio do interesse na competição política pelos agentes que habitam o "topo da hierarquia social". Uma tal situação introduz traços característicos de aristocracia, à medida que se escala "a hierarquia de poder e de prestígio dos cargos em competição" (Gaxie, 1980, p. 6). É desta forma que se verifica um aumento percentual significativo de indivíduos pertencentes às classes superiores "nas hierarquias partidárias", ou quando se percorre a hierarquia dos lugares políticos, das câmaras municipais aos conselhos gerais, passando pelos candidatos a deputados e pelos eleitos deputados e ministros (Gaxie, 1980, p. 6). Nesse livre arbítrio concorrencial, os agentes políticos favorecidos pela sua condição social apossam-se "das posições de poder político reforçando a sua supremacia social e a autoridade política" de que passam a dispor (Gaxie, 1980, p. 6).

A regularidade destas "leis gerais do recrutamento político" (Gaxie, 1980, p. 6) processa-se em termos imutáveis e na ótica da reprodução social dos seus membros, tendo em vista a manutenção de um estatuto atribuído a grupos profissionais determinados. 
Em regra, o recrutamento político funciona com mão dura e são oligárquicas as tendências que prevalecem no funcionamento das organizações políticas (Michels, 2001). Mediadoras de poder social, as organizações políticas têm, com efeito, práticas que conciliam a noção de utilidade pública, fundada na sociedade civil, com a conveniência em instrumentalizar o poder localizado no Estado.

A constatação da existência de uma "partidarização parlamentar e de uma parlamentarização partidária", por Braga da Cruz (1988) constitui o nosso passo inicial para o conhecimento das profissões instaladas na Assembleia da República. André Freire (1998), por sua vez, deu continuidade ao trabalho de Braga da Cruz, completando-o com as legislaturas entretanto decorridas. As transformações sociais, por que passou Portugal nas últimas décadas, obrigaram-nos a introduzir algumas alterações na análise das profissões. No trabalho, ora em apreço, foram também acrescentadas novas profissões, que acederam ao Parlamento português e recompuseram a realidade da Assembleia da República.

\section{EFEITO SUBSTITUIÇÃO E CONSEQUÊNCIAS}

Há três grandes áreas profissionais com predisposição para aceder à Assembleia da República e que, ao longo dos 40 anos da democracia portuguesa, se constituíram na base das profissões dominantes junto do Parlamento. Advogados e juristas, docentes em geral e economistas e análogos são, destacadamente, os grupos profissionais mais representados na Assembleia da República, agrupando dois terços dos mandatos parlamentares entre a VIII e a XIII legislatura, como resultado das eleições legislativas entre 1999 e 2015 (Gráfico 2). Entre 1985 e 2015, o peso destes grupos profissionais na AR não foi sempre igual, embora, grosso modo, possa afirmar-se que as variações entretanto ocorridas, não lhes diminuíram o peso, enquanto forças mais representativas do poder legislativo.

A estes três grupos profissionais dominantes juntam-se o grupo dos engenheiros, nas suas várias especializações, e o grupo dos técnicos intermédios, geralmente agentes especialistas, não dirigentes, de variadas áreas. Tanto um como outro grupo mantêm uma representação constante, ao longo dos anos, embora ligeiramente reforçada na última década (Gráfico 1 e Gráfico 2).

A presença de profissionais da medicina na Assembleia da República cifra-se, em termos históricos, numa média a rondar os 3\% de deputados, sendo, por isso, uma profissão estabilizada dentro do Parlamento. Em contraste, o grupo dos jornalistas e escritores, tal como o grupo dos trabalhadores agrícolas e industriais, denotam, ao longo dos anos, uma tendência regressiva, constando, num e noutro caso, com apenas $1 \%$ dos deputados em 2015. A visão ampla do gráfico apresenta um efeito progressivo de substituição e/ou, em certos casos, diminuição, de alguns grupos profissionais. Nas eleições de 2005, já não é eleito nenhum "dirigente da função pública", categoria que em 1985, na IV legislatura, tinha alguma expressão (5\%), subsistiu com uma relevância aproximada até 1995 (6\%), entrando em decadência na VIII legislatura (3\%), para definhar completamente na IX legislatura. 


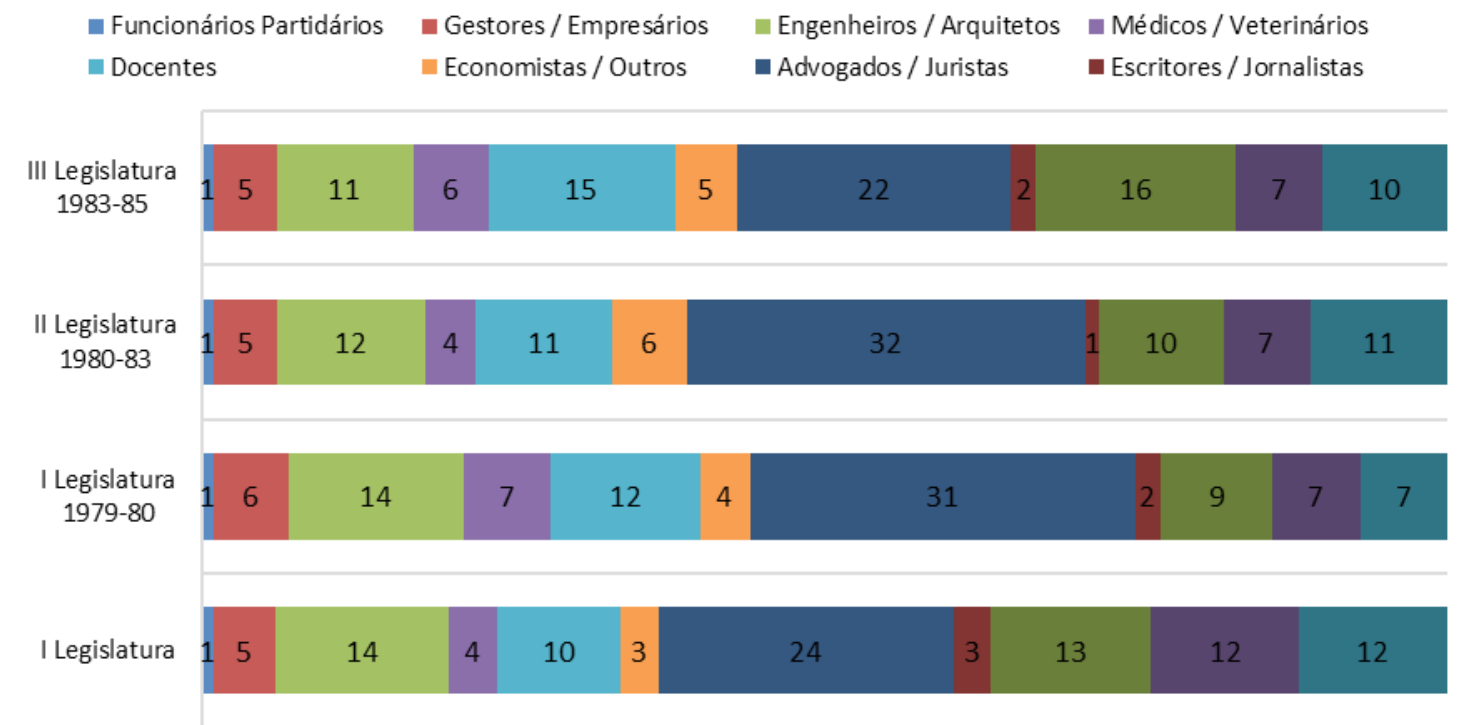

Gráfico 1: Áreas profissionais dos deputados à Assembleia da República (1974-1985)

Fonte: Braga da Cruz, 1988

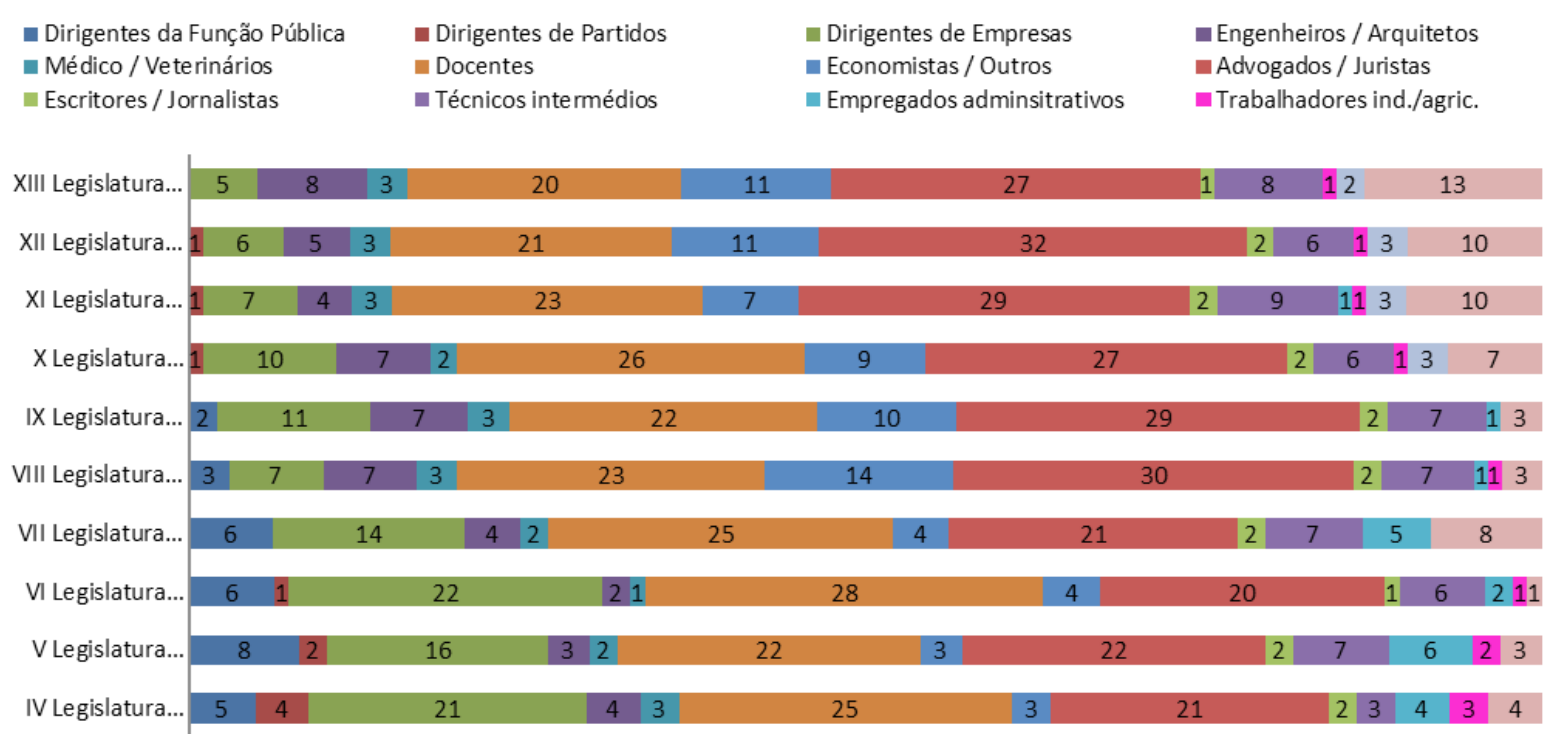

Gráfico 2: Áreas profissionais dos deputados à Assembleia da República 1985-2015 (\%)

Fonte: Braga da Cruz, 1988; Freire, 1998

Este quadro de queda de um grupo profissional manifestou-se, de igual maneira, no caso dos "dirigentes de partidos", categoria que albergou $4 \%$ dos parlamentares, em 1985, mas cedo diminuiu para $1 \%$ dos ativos, denotando uma tendência para o desaparecimento.

Os "empregados administrativos" foram também alvo do efeito de substituição. Tendo chegado a ser 6\% dos deputados, em 1987, persistiram em 1995 (5\%). Mas, a partir de 1999, este grupo profissional praticamente deixou de ter presença junto dos parlamentares do hemiciclo português. 
A saída de cena de algumas profissões teve como consequência o reforço de algumas das profissões já existentes e a entrada de outras, em resultado da dinâmica da Sociedade Civil, que se abriu a novos campos profissionais. Com efeito, tendo ganho algum lastro social, os novos campos profissionais logo procuraram alargar a sua influência, através da sua inclusão política. A partir de 2005, aparece um novo domínio profissional, que se exprime na geometria eleitoral como deputados da área profissional de "consultores e assessores". Este grupo imediatamente estabilizou em $3 \%$ dos deputados. Juntamente com esta nova categoria, surge o alargamento de diversas atividades profissionais, dissemelhantes entre si - e por isso não categorizáveis -, genericamente acumuladas no grupo "outros".

\section{“ECONOMisTAS" E "Dirigentes de EMPRESAS"}

Os economistas configuram um caso particular, se analisado ao longo dos anos. Nas primeiras três legislaturas, entre 1974 e 1985, este grupo profissional alcançou uma representação que atingiu, em 1980-1983, um máximo de 6\% dos deputados (Gráfico 1). Nos anos seguintes, entre as IV e VII legislatura (1985 a 1999), os profissionais de economia não se revelaram muito atreitos à política, oscilando entre $3 \%$ e $4 \%$ de indivíduos. No entanto, a partir da VIII Legislatura, este domínio profissional surgiu em força, junto do poder legislativo, chegando a constituir-se como o terceiro maior grupo profissional no Parlamento, durante os anos 1999-2002, com 14\% dos deputados. Apesar da quebra em 2009 para 9\%, a partir de então os economistas estabilizaram nos $11 \%$ dos eleitos à Assembleia da República (Gráfico 2).

Esta ascensão histórica dos economistas contrasta com o declínio progressivo de um outro grupo profissional, originalmente definido, entre 1974 e 1985, como "Empresários e Gestores" (Gráfico 1). Na primeira década de democracia, estes profissionais oscilaram entre $5 \%$ e $6 \%$ dos deputados na Assembleia da República. O seu auge deu-se nos dez anos decorridos entre 1985 e 1995, período em que as categorias da estatística passaram a ter uma formulação mais próxima das práticas. Em 1985, a nova nomenclatura, "dirigentes de empresas", acolhe $21 \%$ dos mandatos, mas logo encolhe para $16 \%$ dos deputados, em 1987. A aposta na política deste grupo profissional volta a manifestar-se em força, em 1991, quando chega aos 22\% dos parlamentares. Em 1995, os indivíduos ligados à direção de empresas ainda atingem 14\% dos mandatos legislativos, mantendo assim uma forte presença no Parlamento. Mas, começa aí a seu declínio. A partir de 1999, com relevância para o período entre 2005 e 2015, a classe profissional dos "dirigentes de empresas" vai-se afastando, gradualmente, da Assembleia da República, reduzindo o número de deputados, até chegar a 5\% de parlamentares, em 2015.

\section{“AdVOGADOS" E "DOCENTES"}

O Parlamento apresenta um predomínio histórico, tanto de advogados como de docentes (Freire, 1998), constituindo os dois grupos profissionais mais estabilizados, ao longo dos 40 anos da democracia portuguesa. A regularidade destas profissões na 
Assembleia da República, funcionando como alicerce estrutural do Parlamento, denota a sua consolidação.

No caso dos advogados, profissão coincidente com a formação em direito, é reconhecida uma interligação entre as necessidades produtivas da instituição e a posse de competências na produção técnica legislativa pelos profissionais da área. Para o seu predomínio na Assembleia da República, não são alheias, também, as "qualidades de tribuno" (Freire, 1998, p. 126), um requisito sempre necessário num espaço, em que a afirmação do profissional também ocorre pela qualidade da oratória utilizada.

A alta expressão numérica, assim como a regularidade histórica do grupo profissional dos docentes, revela uma predisposição para o campo político, de indivíduos na posse de "posições socioprofissionais associadas a um volume intermédio de recursos - em capital económico, organizacional e escolar" (Freire, 1998, p. 129).

Enquanto categorias dominantes na Assembleia da República, advogados e docentes exprimem, por outro lado, uma regularidade assinalável. A partir de 1999, passaram a comportar mais de 50\% dos mandatos parlamentares. Em 2015, com a XIII legislatura, ocorre, todavia, uma diminuição do agregado de presenças destes dois grupos profissionais em $3 \%$, de modo que agora se cifra em $47 \%$ dos agentes parlamentares.

A diminuição de presenças do somatório destes dois grupos profissionais está associada ao efeito de substituição, que se tem operado, com o alargamento fragmentário de novas atividades profissionais, introduzidas no Parlamento. Essa tendência adquire expressão visível em 2009, tendo atingido os $13 \%$ dos lugares parlamentares em $2015^{2}$.

\section{ACUMULAÇÃo EXTRAPOLÍtiCA: UM PÉ DENTRO E OUTRO FORA}

Existem parlamentares que mantêm atividades civis, em concomitância com as funções políticas que exercem. Aparentemente, os deveres de lealdade e independência, que atravessam a atividade parlamentar, podem ter uma interpretação particular. Cerca de dois terços (68\%) dos 230 deputados à Assembleia da República declararam dedicar-se exclusivamente à atividade política parlamentar. Mas os restantes $32 \%$ assinalaram que exercem outras ocupações, para além do trabalho político regular, no órgão legislativo da República Portuguesa ${ }^{3}$ (Gráfico 3$)^{4}$.

\footnotetext{
${ }^{2}$ Em termos absolutos, são 31 registos. Nestes, 9 remetem para atividades profissionais (atriz, assistente, bancário, investigador), 13 indicam a área académica como profissão (o que inclui: sociólogos, psicólogos, historiadores, matemáticos, químicos, arqueólogos, geólogos), dois são estudantes, três reformados, e quatro mantêm o espaço em branco.

3 Dados de recolhidos em maio de 2016, no portal da Assembleia da República, e que deram origem ao estudo "Os Acumuladores", do Observatório da Democracia Interna dos Partidos Políticos, do Movimento pela Democratização dos Partidos. Retirado de https://tinyurl.com/yapxhgr8

${ }_{4}$ Os dados usados nesta secção foram colhidos e cedidos pelo Movimento pela Democratização dos Partidos Políticos, vindo posteriormente a ser testados pelo autor.
} 


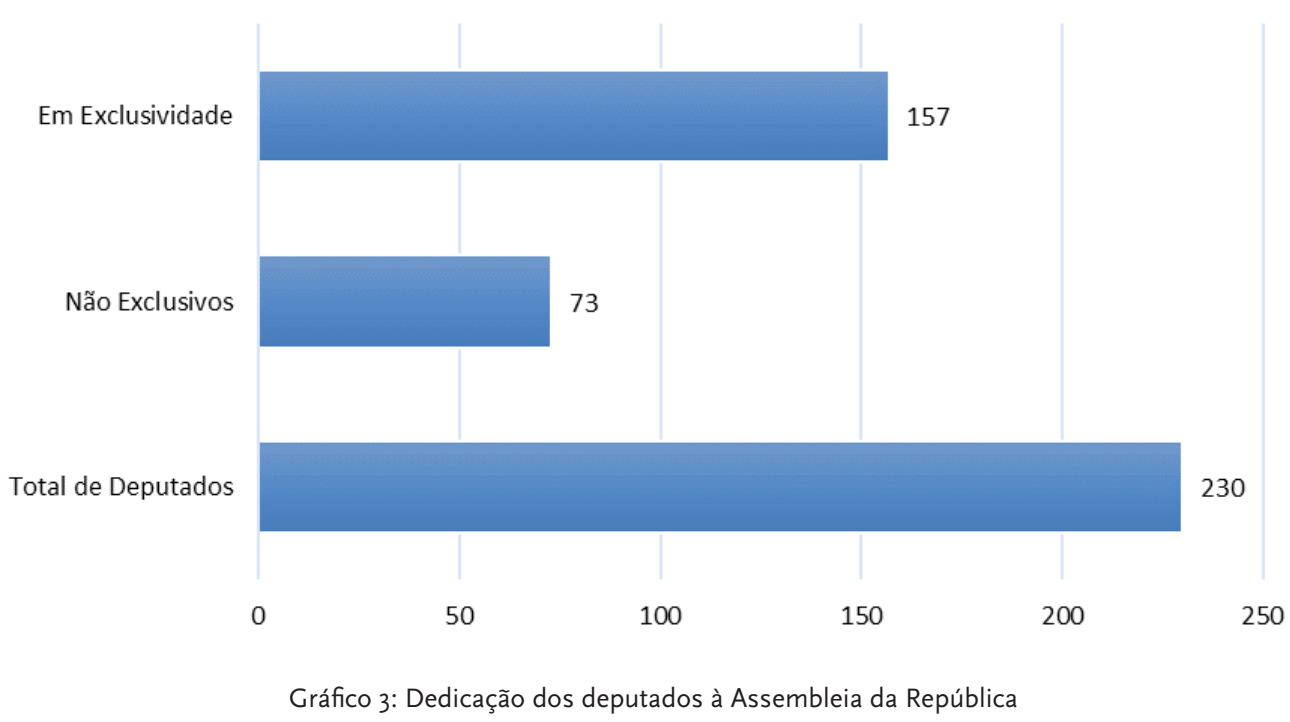

São os advogados e as atividades empresariais (de administrador, gestor e sócio-gerente), as profissões mais atreitas à acumulação (69\%). Esta circunstância demonstra a tendência destes misteres, não apenas para acesso e domínio da Assembleia da República, como também para identificar áreas de poder, que permitam estabelecer uma via que se reparta entre a vida pública e a vida civil.

A presença dos "consultores" em valores razoáveis de acumulação de atividades (10\%) demonstra a relevância que este grupo profissional tem ganho - tal como atrás é assinalado (Gráfico 3). Neste particular, os "consultores" são seguidos, a uma considerável distância, de atividades técnicas, como as de médico (4\%), e engenheiros e arquiteto $(3 \%)$, que declaram não prescindir da sua profissão civil, quando se dedicam à política. A atividade universitária, entendida em termos pedagógicos, de lecionação (14\%), revela também uma predisposição da docência, considerada ao nível superior, para a acumulação com a ação política (Gráfico 4).

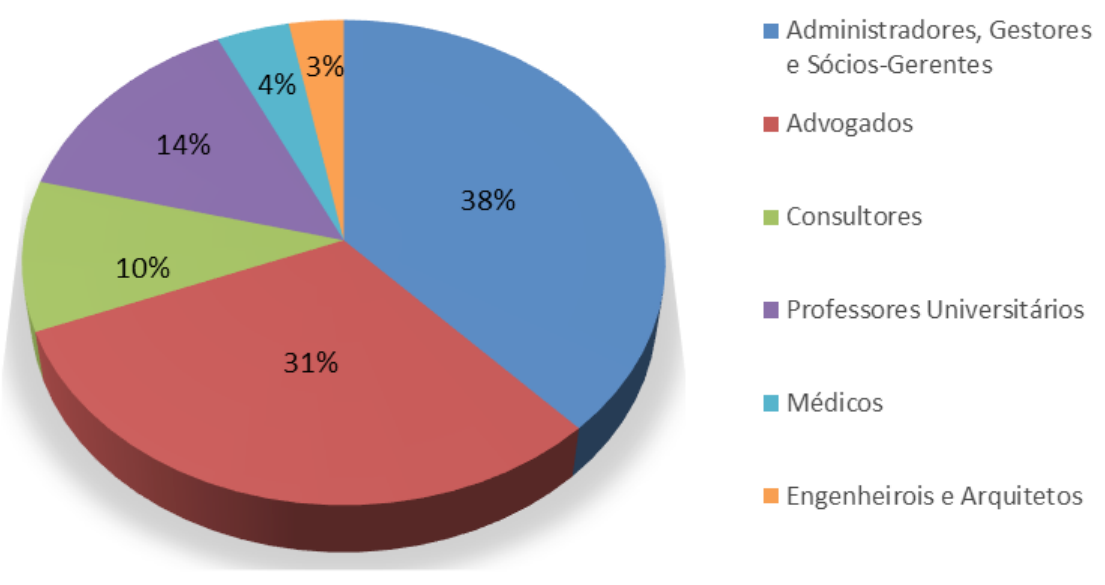

Gráfico 4: Última profissão civil dos deputados à Assembleia da República em situação de acumulação 
Por regra, a maior parte dos parlamentares com acumulações apresenta uma única função extrapolítica. Em casos extraordinários, esta tendência é reforçada por indivíduos que chegam a acumular com a prática de deputado variadas funções externas 5 , mesmo em circunstâncias passíveis de a sua atividade parlamentar colidir com interesses e obrigações particulares, entretanto constituídos.

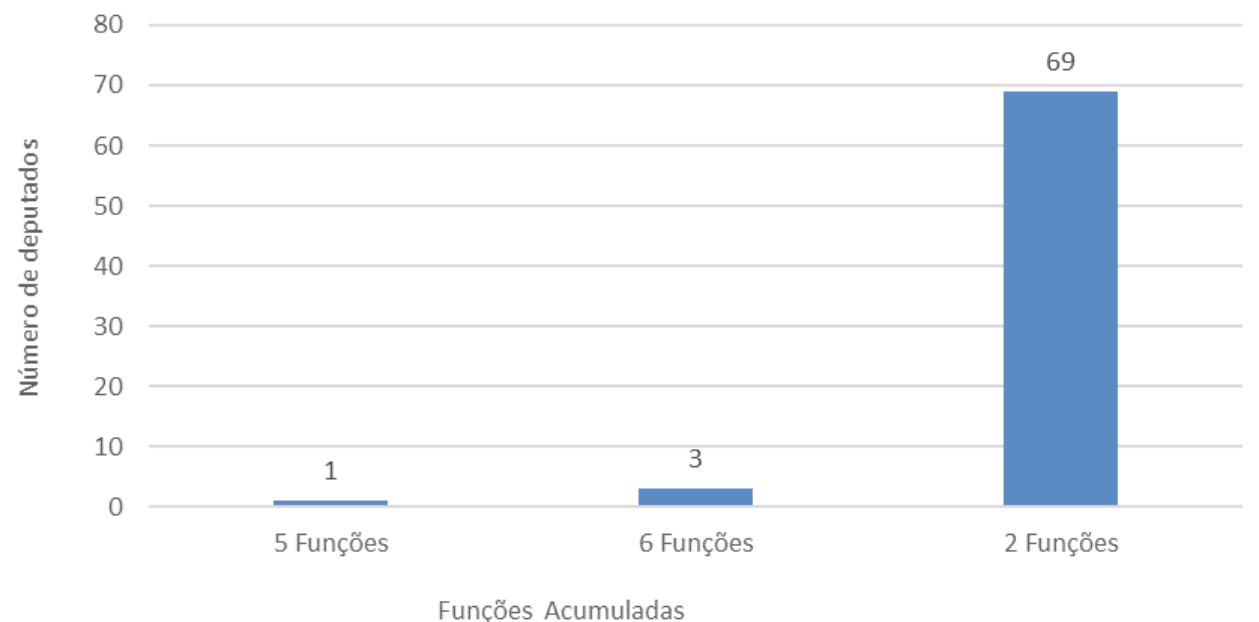

Gráfico 5: Funções extrapolíticas acumuladas por deputado acumulador

O Partido Social Democrata (PSD) apresenta o maior número relativo de deputados com atividades extrapolíticas (37 em 89), sendo imediatamente seguido pelo CDS, que apresenta uma relação quase idêntica (sete em 18). A alguma distância, mas revelando a mesma predisposição, o Partido Socialista apresenta praticamente um terço (28 em 86) dos seus deputados, com vida ativa repartida entre o estado e a profissão civil. O Partido Comunista Português completa o quadro de deputados com profissões e atividades extrapolíticas, numa relação reduzida (um em 15). Esta relação partidária dos deputados com profissões exercidas fora da política tem a particularidade de crescer no sentido da esquerda para a direita política, manifestando-se uma ausência de casos, tanto no Partido Ecológico Os verdes, como no Bloco de Esquerda (Gráfico 6).

\footnotetext{
${ }^{5}$ Alguns casos detalhados de acumulações: Fernando Anástácio - eleito pelo círculo de Faro, declara ser, também, administrador da sociedade de advogados Fernando Anastácio \& Associados, administrador da empresa de consultoria Lucksin SA, presidente do Conselho de Administração da Procota, Presidente do Conselho de Administração da Quinta do Escarpão (ambas do ramo de imobiliária e turismo) e Presidente da Mesa da Assembleia Geral da Mundo Aquático (parques temáticos). Luís Montenegro - eleito por Aveiro, exerce advocacia na sociedade SP\&M (tem quota de 50\%), é Presidente da Assembleia Geral da Rádio Popular - Eletrodomésticos, SA, membro da CADA (Comissão de Acesso aos Documentos Administrativos), da qual cessou atividade em março de 2017, e Presidente da Assembleia Municipal de Espinho. Nuno Magalhães - eleito por Setúbal, é professor convidado da Universidade Lusófona, deputado na Assembleia Municipal de Setúbal, além de comentador da Sport TV (desde 9.8.2016). Ver Registo de interesses da Base de Dados da Assembleia da República, disponível em http://www.parlamento.pt/DeputadoGP/Paginas/Deputadoslista.aspx
} 


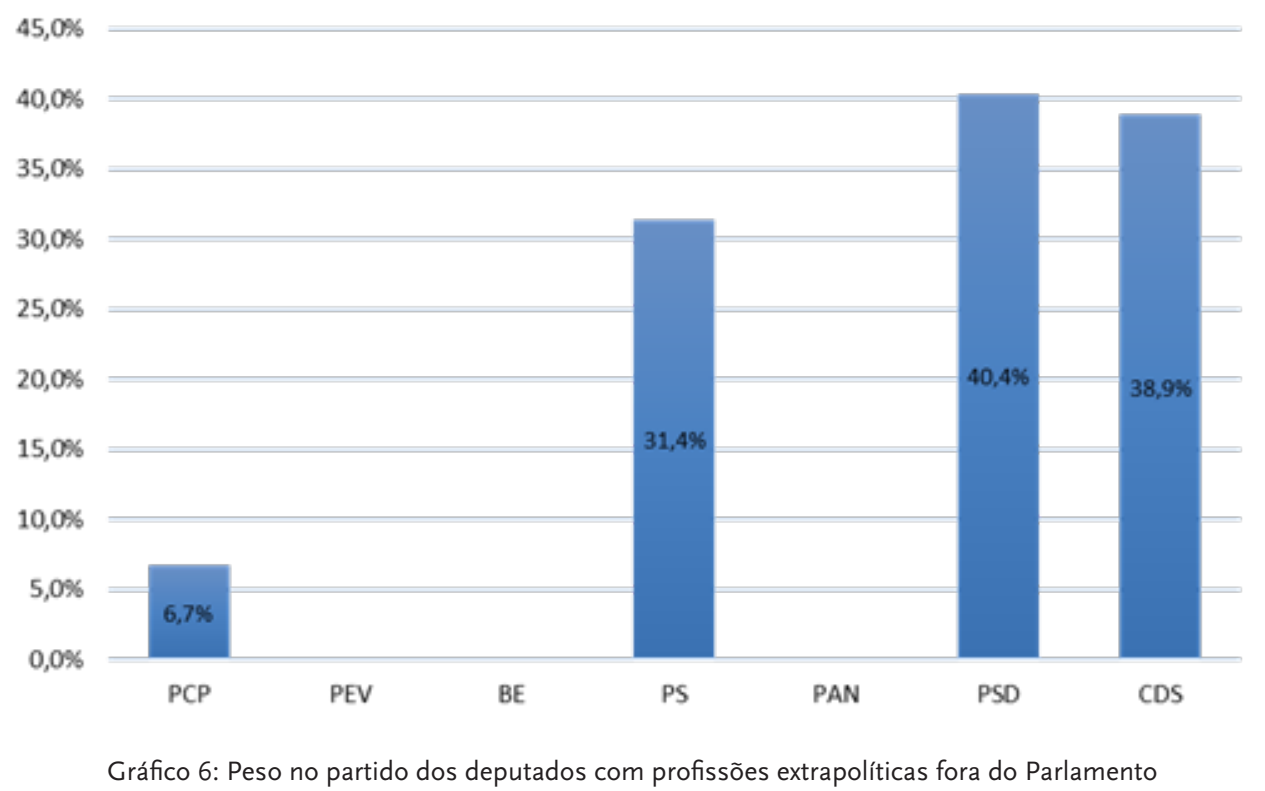

Os dados expostos sobre as acumulações dos deputados à Assembleia da República Portuguesa permitem, numa leitura global, duas interpretações. Por um lado, a acumulação pode ser apresentada como uma condição da independência do político face ao lugar ocupado. Tratar-se-ia, neste caso, de garantir a subsistência fora da política, assim demonstrando que a prática política não constitui um fim profissional (Weber, 2005a). No entanto, a entrega abnegada, desprendida, assente na franqueza (Foucault, 2008), enquanto constituinte da verdadeira "essência do político" (Freund, 1969), nunca se verifica na totalidade. $O$ "passo em frente" e o agir francamente, como instrumentos de lealdade para consigo e para com os outros (Foucault, 2008), ficam desde logo limitados, ficando, pois, diminuído o valor real do político, se nos cingirmos ao indivíduo.

Neste caso, o "passo em frente" não se concretiza, por inteiro, e, ao contrário do preconizado por Foucault (2008), dá-se o caso de o candidato a agente político usar como estratégia a popular fórmula de manter "um pé dentro e outro fora". E, nestas circunstâncias, a tendência para atividades extrapolíticas pode constituir apenas a demonstração da predisposição do indivíduo para o uso do cargo político como um instrumento que incremente a atividade privada. Ou seja, como instrumento que permita o acesso a proventos que, de outra forma, não existiriam. Neste caso, o político apresenta-se como uma espécie de empresário, que entrevê na atividade política uma plataforma de ampliação das suas possibilidades em favor dos seus interesses privados. Desta forma, o político não é mais do que uma pessoa de negócios, que vê a política como mais uma ferramenta para conseguir contratos, realizar transações e convénios, tendo como objetivo a acumulação física de capital (Weber, 2005a). Mantém-se aqui o entendimento de que a prática política deve ser encarada como uma atividade que se situa no mesmo patamar de uma outra qualquer. E à falta de fronteiras entre as atividades, política e privada, exercita-se a complementaridade. O que esta situação também revela é que o acesso a um cargo político se processa numa luta em que o vencedor fica, desde logo, 
na posse de um poder que o autoriza a agir num campo em que os limites são por si próprios ditados.

A coexistência na Assembleia da República de deputados com acumulações profissionais extrapolíticas e de deputados dedicados exclusivamente à propositura política mostra-se, pelo menos em público, pacífica e inquestionada. Não é produzida qualquer denúncia ou crítica que permita demonstrar a existência de qualquer conflitualidade entre as duas situações. Aparentemente, todos estão a favor da possibilidade de acumulação. Pelo menos, não vislumbram qualquer aspeto negativo, nem potencialmente negativo, nesta atividade repartida, que coloca o indivíduo na política e, em simultâneo, lhe dá a possibilidade de agir, profissional e empresarialmente, no campo civil. Mas entre o deputado em regime exclusivo e o deputado em regime não exclusivo, formam-se duas figurações de sentido (Elias, 1971). No primeiro caso, temos um político inteiro, que consagra a sua ação, absoluta e integralmente, aos afazeres da política. No segundo, temos um político dividido, cuja ação se reparte por vários domínios. Esta situação coloca-o na contingência de ter que justificar os seus atos, demonstrando que os domínios privados a que se dedica não colidem com a sua atividade pública.

\section{TEORIA POLÍTICA DOS IMPEDIMENTOS - DO IMPLÍCITO AO EXPLÍ́CITO}

Na sua origem conceptual, ter parresía não é um caso de oportunidade, ou um impulso do momento. Não resulta de um cálculo com objetivo diverso dos fins em que a

política se situa. É, sim, ter vontade constituída de se aproximar da frente numa convicção interna, que não inclui outra intenção. Decorre não "em função da riqueza mas em função do problema da dýnamis" (Foucault, 2008, p. 142), em que há que ter em conta "três categorias de cidadãos" (Foucault, 2008, p. 142):

- os "impotentes", que não têm força para exercer o poder - o povo em geral;

- os ricos e bem-nascidos, que na qualidade de sábios não se ocupam de nada e que, ao calarem-se, não "utilizam a parresía" potencial provinda do conhecimento;

- "os que efetivamente se ocupam da cidade", sendo apenas estes que encarnam e se servem da parresía (Foucault, 2008, p. 143), que é algo distinto da condição estatutária ou de qualquer obrigação imposta pela cidadania.

Por se tratar de uma exclusividade cometida a uma reduzida categoria de pessoas, o recurso à parresía acarreta grandes problemas, designadamente "riscos e perigos" aos que dela se servem para intervir na cidade. Neste contexto, é reconhecida, por exemplo, a exposição, que também os sujeita ao ódio dos impotentes, à troça dos sábios e, em geral, à "rivalidade e à inveja" das outras categorias, as quais, de um ou outro modo, circulam pela cidade. Assim, a parresía define "certa posição de certos indivíduos" (Foucault, 2008, p. 144) e consubstancia-se na diferenciação, reconhecida "por certa superioridade que também é uma ambição e um esforço para se ver numa posição tal, que possa dirigir os outros" (Foucault, 2008, p. 144). O reconhecimento da posse destes 
atributos, idênticos entre elementos que se encontram destacados da restante população, direciona-os para um tipo de fusão tendencialmente associativa.

Os deputados eleitos à Assembleia da República configuram um desses encontros entre pares, possuídos por um interior orientado para a ação arrojada (Foucault, 2008). Contudo, alguns não se coíbem de participar, individual ou societariamente, em empresas com contratos com o Estado. Esses deputados fazem parte do conjunto de parlamentares com atividades extrapolíticas mas, entre si, constituem uma prática diferenciada, que coloca a atividade civil no centro da sua existência profissional. No caso, - Estado e os seus organismos são usados e colocados no lugar de clientes (ver Tabela 1). Nesta equação, o papel de deputado reveste-se de um significado tático, que o metamorfoseia num mediador entre a profissão civil e os clientes da órbita estatal.

Com as suas empresas, conquistam a atividade profissional civil, junto de entidades públicas do seu círculo eleitoral, ou de círculos eleitorais vizinhos, os quais estão submetidos aos órgãos autárquicos ou governo regional - no caso da Madeira. Os negócios são sempre dominados pelo seu partido e obtidos em regime de "ajuste direto", facilitados pela ausência de concurso público (ver Tabela 1). A associação estabelecida entre os agentes e as formas de agir produz uma configuração tipológica em que o centro de encontro entre as partes, de gestação estratégica e de divisão do poder se localiza na elite dirigente dos partidos políticos.

Esta prática revela a predisposição para algo mais do que a estratégia de manutenção de um pé dentro da política e outro pé fora na atividade civil, como atrás foi demonstrado. Neste caso, a metáfora do movimento dos pés revela, não uma expetativa de separação dos campos, decorrente do receio de falhanço enquanto político, mas um expediente de ligação entre os dois domínios, tendo em vista as possibilidades de ação junto de outras instituições do Estado. O facto de a atividade civil poder servir de interface para a manipulação particular de entidades públicas, visando a realização de atividades económicas, reduz a atividade política à subalternidade, com o poder do deputado a submeter-se ao poder de agente partidário.

\begin{tabular}{|c|c|c|c|c|c|c|c|c|}
\hline 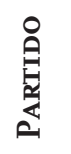 & $\begin{array}{l}\text { NoME DO } \\
\text { DEPUTADO }\end{array}$ & $\begin{array}{c}\text { CíRCU- } \\
\text { LO ELEI- } \\
\text { TORAL }\end{array}$ & $\begin{array}{l}\text { PERÍO- } \\
\text { DO DO } \\
\text { NEGó- } \\
\text { CIO }\end{array}$ & $\begin{array}{c}\text { ATIVIDADE } \\
\text { EXTRAPAR- } \\
\text { TIDÁRIA }\end{array}$ & EMPRESA & 它是 & $\begin{array}{l}\dot{z} \text { n } \\
0 \\
0 \\
0 \\
\dot{z}\end{array}$ & VALOR \\
\hline PS & José Rui Cruz & Viseu & 2015 & Sócio-gerente & Frutas Cruz II, Lda. & $34 \%$ & 20 & $164.000,00 €^{6}$ \\
\hline \multirow{2}{*}{ PSD } & \multirow{2}{*}{$\begin{array}{l}\text { Fernando Virgílio } \\
\text { Macedo }\end{array}$} & \multirow{2}{*}{ Porto } & \multirow{2}{*}{2011} & \multirow{2}{*}{ Sócio-gerente } & $\begin{array}{l}\text { Virgílio Macedo, } \\
\text { SROC, Unip. Lda. }\end{array}$ & $100 \%$ & 2 & $83.000,00 €^{7}$ \\
\hline & & & & & $\begin{array}{l}\text { Rodrigo, Gregório } \\
\text { \& Associados }\end{array}$ & $33 \%$ & 7 & $168.000,00 €$ \\
\hline PSD & Luís Montenegro & Aveiro & $\begin{array}{l}2014 \\
-2017\end{array}$ & Sócio & $\begin{array}{l}\text { Sousa Pinheiro \& } \\
\text { Montenegro }\end{array}$ & $50 \%$ & 6 & $188.000,00 €^{8}$ \\
\hline PS & Ricardo Bexiga & Porto & 2016 & Sócio & $\begin{array}{l}\text { Ricardo Bexiga, Oliveira } \\
\text { e Silva \& Associados }\end{array}$ & $60 \%$ & 5 & $200.000,00 €^{9}$ \\
\hline PS & Luís Moreira Testa & Portalegre & 2016 & Sócio & CCP Associados & $15,39 \%$ & 1 & $2.400,00 €^{10}$ \\
\hline
\end{tabular}




\begin{tabular}{|c|c|c|c|c|c|c|c|c|}
\hline PS & Renato Sampaio & Porto & $\begin{array}{l}2009 \\
-2017\end{array}$ & Porto & $\begin{array}{l}\text { Nuno Sampaio - } \\
\text { Arquiteto Lda. }\end{array}$ & $85 \%$ & 15 & $716.000,00 €^{11}$ \\
\hline PSD & $\begin{array}{l}\text { Paulo Rios } \\
\text { de Oliveira }\end{array}$ & Porto & & Advogado & $\begin{array}{l}\text { Rios, Pinho \& Cris- } \\
\text { to, Soc. Avogados }\end{array}$ & $45 \%$ & 1 & $14.000,00 €^{12}$ \\
\hline PSD & Guilherme Silva & Madeira & $\begin{array}{l}2009 \\
-2015\end{array}$ & Advogado & Age individualmente & $100 \%$ & 25 & $638.000,00 €^{13}$ \\
\hline
\end{tabular}

Tabela 1: Deputados sócios de empresas com contratos públicos

Fonte: O Jornal Económico de 17 de março de $2017^{14}$

As estratégias surgidas nos interstícios dos aparelhos partidários formam-se em progressões dinâmicas, nas quais o processo gradativo latente orienta a praxis e os expedientes recursivos (Giddens, 1984). As práticas decorrentes da vivência ativa nos lugares de comando submetem os indivíduos, pelo menos "no plano dos princípios" (Michels, 2001, p. 416), a uma classe que não é a sua de origem, dando-se assim, através das rotinas, uma mutação do agente instigador de "uma contradição de interesses" (Michels, 2001, p. 416). Esta dissonância é resolvida, todavia, através do recurso a novas crenças do agir, que harmonizam o interior do agente, com o objeto exterior da sua ação (Festinger, 1962). Na disputa interior entre os diversos interesses em competição, a "decisão assenta sempre na maior força de atração, ou seja, na relação em que os interesses se encontram com as necessidades mais importantes da vida" (Michels, 2001, p. 416), o que tem, objetivamente, reflexos imediatos em fatores de ordem económica. Nesta mutação espirituosa, produzida na oposição das dinâmicas práticas constitutivas da realidade, "o antagonismo económico ultrapassa então a solidariedade ideológica e inscreve-se visivelmente na ordem do dia" (Michels, 2001, p. 416). Deste modo, o programa - original ato fundador das convenções políticas desejadas - é relegado para o lugar de um documento sem valor para as práticas dos atos políticos empreendidos.

\footnotetext{
${ }^{6}$ Contratos efetuados com a Guarda Nacional Republicana e duas escolas públicas.

7 Empresa de que a Virgílio Macedo, SROC, possui 33,33\% do capital. Dois contratos, por ajuste direto, que importaram em 58 mil euros, um com o Município de Valongo, em 2014, e o outro com o Município de Vila Nova de Gaia, em 2013.

${ }^{8}$ Foi Presidente da Assembleia Municipal de Espinho (2009-2013) e vereador do município Espinho (1997-2001). Existem quatro contratos com a Câmara Municipal de Espinho (presidida por Joaquim Pinto Moreira, do PSD) e 2 com a Câmara Municipal de Vagos (presidida por Silvério Regalo, do PSD).

${ }^{9}$ Contratos efetuados com o Município de Valongo, presidida por José Ribeiro, do PS.

10 Sócio da UP2Com (33,3\%). Contrato efetuado com a Câmara de Portel.

"A empresa é detida em $15 \%$ pelo filho e $85 \%$ pela esposa. Os contratos foram realizados com a Administração Regional de Saúde do Norte, Município de Castelo Branco, Instituto Politécnico do Porto, etc. Em março de 2010, a Parque Escolar adjudicou a "elaboração do projeto de arquitetura" de uma escola em Castelo de Paiva, por mais de 204 mil euros, sem realizar um concurso público.

${ }^{12}$ Membro da Subcomissão de Ética e da Comissão Eventual para o Reforço da Transparência no Exercício de Funções Públicas.

${ }^{13}$ Contratos obtidos, através de "ajustes diretos" de entidades públicas (vice-Presidência do Governo Regional da Madeira, Assembleia Legislativa da Região Autónoma da Madeira, Universidade da Madeira, Estradas da Madeira, etc.).

14 Dados coligidos, a partir do "registo de Interesses" dos deputados à Assembleia da República e dos contratos registados na base de dados dos contratos públicos, efetuados com o Estado. Retirado de http://www.base.gov.pt/Base/pt/ Homepage.
} 


\section{CONSIDERAÇõES FINAIS}

Os partidos são organizações submetidos a uma doutrina de classe política (Albertoni, 1987), constituídos como comunidades associativas, de captura e distribuição de poder entre os seus membros. Esta circunstância faz deles aparelhos que têm como objetivo o uso da força acumulada, por um lado, para a "imposição de um programa por motivos ideais ou materiais" (Weber, 2004, p. 185), e por outro lado, para a aquisição de "prebendas", ou seja, de favores do Estado, que de outro modo seria impossível adquirir. Enquanto o primeiro objetivo visa ao (pre)domínio da organização, o segundo tem por objetivo exclusivo o alcance de autoridade, traduzido no reconhecido social da posse de "honra para seus líderes e partidários" (Weber, 2004, p. 186). Na base de um entendimento do partido político moderno, a ação dos seus membros pouco se orienta, praticamente nada, para o reforço ideológico. Orienta-se, sobretudo, para a conquista patrimonial, prática que recupera a noção de "domínio 'político'", em que o poder doméstico é agregado "a outras relações de dominação", concebidas, estrutural e sociologicamente, de acordo com "os dois poderes especificamente políticos (...), o poder militar e o judicial". À semelhança do que sucedia na antiguidade, tais poderes são exercidos "ilimitadamente sobre aqueles que lhe estão patrimonialmente submetidos" (Weber, 2004, p. 240).

A circunstância de uma "lei de impedimentos" se opor a todas as acumulações, cuja possibilidade é negada, mas que na realidade são permitidas, dada a ausência de uma referência explícita à realidade potencialmente interdita, mas que não interessa impedir ${ }^{15}$, mostra como as leis do campo político alcançam uma intenção, decorrente do costume, assim estabelecendo e organizando, com a forma de leis, as coordenadas "do universo das técnicas de ação e de expressão". Desta forma, ao promover-se a "passagem do implícito ao explícito", na manifestação pública da obrigação legal, realiza-se "um ato de instituição", apenas com uma força aparente de transformação, porque esse ato representa uma mera "forma de oficialização, de legitimação" (Bourdieu, 1981, p. 4) de uma realidade legal, que é obrigatoriamente aceitável, precisamente porque é legal.

No campo político, cabe aos membros, tornados especialistas, levar a cabo o empreendimento da produção das "formas de perceção e de expressão politicamente atuantes e legítimas" (Bourdieu 1981, p. 4). É desse modo que se arquiteta um limitado corpo de "unidades produtivas" (Bourdieu, 1981, p. 4), que se estabelece como monopólio de profissionais. Trata-se de um reduzido número que funciona sob constrangimento e o controlo dos mesmos profissionais que o constituem.

\footnotetext{
${ }^{15} \mathrm{O}$ exemplo está patente no artigo $21 .^{\circ}$ do Estatuto dos Deputados, que alude aos "impedimentos" e que veda à atividade de deputado quem esteja "no exercício de atividade de comércio ou indústria, direta ou indiretamente, com o cônjuge, não separado de pessoas e bens, por si ou entidade em que detenha participação relevante e designadamente superior a $10 \%$ do capital social, [está impedido de] celebrar contratos com o Estado e outras pessoas coletivas de direito público, participar em concursos de fornecimento de bens ou serviços, empreitadas ou concessões, abertos pelo Estado e demais pessoas coletivas de direito público, e, bem assim, por sociedades de capitais maioritária ou exclusivamente públicos ou por concessionários de serviços públicos". Note-se a preocupação em não impedir negócios em empresas participadas e, em simultâneo, a ausência total no que diz respeito a impedimentos das profissões dominantes na Assembleia da República, com tendência para atividades extrapolíticas (Cf. Gráfico 4 e Tabela 1).
} 


\section{REFERÊNCIAS BIBLIOGRÁFICAS}

Albertoni, E. A. (1987). Doctrine de la classe politique et théorie des élites. Paris: Librairie des Méridiens.

Barthes, R. (1970). L'ancienne rhétorique. Communications, 16(1), 172-223.

Belchior, A. M. (2011). Democracia e Representação Partidária - A elite parlamentar e os cidadãos. Lisboa: Imprensa de Ciências Sociais.

Bourdieu, P. (1981). La représentation politique - Éléments pour une théorie du champ politique. Actes de la recherche en sciences sociales., 36-37, 3-24. Retirado de http://www.persee.fr/doc/ arss_0335-5322_1981_num_36_1_2105

Bourdieu, P. (2012). Sur l'État. Cours au Collège de France 1989-1992. Paris: Seuil.

Braga da Cruz, M. (1988). Sobre o Parlamento português: partidarização parlamentar e parlamentarização partidária. Análise Social, 24(100), 97-125.

Burton, M., \& Higley, J. (2001). The Study of Political Elite Transformations. International Review of Sociology, 11(2), 181-199. doi: 10.1080/713674040

Dal Bó, E., Dal Bó, P., \& Snyder, J. (2009). Political dynasties. Review of Economic Studies, 76(1), 115-142. doi: $10.1111 / j .1467-937 X .2008 .00519 . x$

Elias, N. (1971). Sociology of Knowledge: New Perspectives: Part One. Sociology, 5(2), 149-168. doi: $10.1177 / 003803857100500201$

Fernandes, T. (2014). Sociedade Civil. Lisboa: Fundação Francisco Manuel dos Santos.

Festinger, L. (1962). A theory of cognitive dissonance (vol. 2). Stanford: Standford University Press.

Foucault, M. (1994). História da sexualidade - O cuidado de si. Lisboa: Relógio D’Água.

Foucault, M. (2008). Le Gouvernement de soi et des autres. Cours au Collège de France. 1982-1983. Paris: Seuil.

Freire, A. (1998). Lógicas do recrutamento parlamentar - Os deputados portugueses, 1975-1999. Sociologia Problemas e Práticas, 28, 115-147.

Freund, J. (1969). L’Essence du Politique. Paris: Sirey.

Freund, J. (2003). Sociologia de Max Weber. Rio de Janeiro: Forense Universitária.

Gaxie, D. (1980). Les logiques du recrutement politique. Revue française de science politique, 5-45. doi: $10.3406 /$ rfsp.1980.393877

Giddens, A. (1984). The Constitution of Society - Outline of the Theory of Structuration. Berkeley: University of California Press.

Goffman, E. (1986). Frame analysis - an essay on the organization of experience. Boston: Northeaste.

Higley, J. (2010). Elites e Democracia. Lisboa: Livros Horizonte.

Jalali, C. (2017). Partidos e Sistemas Partidários. Lisboa: Fundação Francisco Manuel dos Santos.

Jalali, C.; Silva, P. \& Silva, S. (2012). Givers and takers: Parties, state resources and civil society in Portugal. Party Politics, 18(1), 61-80.

Joly, H. (2005). Le elites politiques: regard croisé sur le cas français. CIRAC, Cergy-Pontoise, 149-167.

Lisi, M. (2011). Os Partidos Políticos em Portugal - Continuidade e Transformação. Lisboa: Almedina. 
Martins, M. L. (1993). A epistemologia do saber quotidiano. Revista Crítica de Ciências Sociais, 37, 79-100.

Martins, M. L. \& Grácio, R. (Eds.) (2009). Comunicação e Sociedade, 16, Comunicação, Argumentação e Retórica.

Martins, M. \& Neves, J. P. (2000). As lágrimas amargas da participação: como pensar o "poder" a partir de Michel Foucault. Cadernos do Noroeste, 13, 51-65.

Michels, R. (2001). Para uma Sociologia dos Partidos Políticos. Lisboa: Antígona.

Mills, C. W. (1956). The Power Elite. Nova Iorque: Oxford University Press.

Mosca, G. (1923). Elementi di Scienza Politica. Torino: Fratelli Bocca.

Pareto, V. (2004). Circulação das Elites. In M. Braga da Cruz (Ed.), Teorias Sociológicas - Os Fundadores e os Clássicos (pp. 449-457). Lisboa: Gulbenkian.

Parsons, T. (1939). The Professions and Social Structure. Social Forces, 17(4), 457-467. doi: 10.2307/2570695

Rothe, M. (2011). Le courage de la vérité. Le gouvernement de soi et des autres II. Cours au Collège de France (1984) by Michel Foucault. Ancient Philosophy, 31(2), 475-478. doi: 10.5840/ancientphil201131243

Schmitt, C. (2015). O Conceito do Político. Lisboa: Edições 70.

Weber, M. (2004). Economia e Sociedade - Vol. II. S. Paulo: Editora Universidade de Brasília.

Weber, M. (2005a). A Política como Vocação. In Três Tipos de Poder e Outros Escritos. Lisboa: Tribuna da História.

Weber, M. (2005b). Conceitos Sociológicos Fundamentais. Lisboa: Edições 70.

\section{NOTAS BIOGRÁFICAS}

Esser Silva é doutorando no programa doutoral da Fundação Ciência e Tecnologia "Estudos de Comunicação: Tecnologia, Cultura e Sociedade" financiado pelo Projeto FCT PD/BD/52617/2014. Mestre em Sociologia com especialização em Organizações e Recursos Humanos. Dedica-se ao estudo da cultura política e investiga as estratégias de formação dos profissionais da política.

E-mail: esser.jorge@gmail.com

Morada: Centro de Estudos de Comunicação e Sociedade, Campus de Gualtar, Universidade do Minho, Braga 4710-057, Portugal

Moisés de Lemos Martins é Professor de sociologia da cultura e da comunicação na Universidade do Minho (Braga, Portugal), sendo nesta universidade Diretor do Centro de Estudos de Comunicação e Sociedade (CECS), que fundou em 2001. É autor de uma vasta obra académica no campo da epistemologia e sociologia da comunicação.

E-mail:moisesm@ics.uminho.pt; moiseslmartins@gmail.com

Morada: Centro de Estudos de Comunicação e Sociedade, Campus de Gualtar, Universidade do Minho, Braga 4710-057, Portugal 
* Submetido: 31-05-2017

* Aceite: 06-07-2017 